\title{
Chronic mild stress decreases survival, but not proliferation, of new-born cells in adult rat hippocampus
}

\author{
Kuem-Ju Lee ${ }^{2}$, Sung-Jin Kim ${ }^{1}$, \\ Suk-Won $\mathrm{Kim}^{1}$, Song-Hyen $\mathrm{Choi}^{2}$, \\ You-Chan Shin ${ }^{1}$, Sang-Ha Park ${ }^{1}$, \\ Bo-Hyun Moon ${ }^{2}$, Eujin Cho', \\ Min-Soo Lee ${ }^{3}$, Sang-Hyun Choi ${ }^{1}$, \\ Boe-Gwun Chun ${ }^{1}$ and Kyung-Ho Shin ${ }^{1,4}$ \\ ${ }^{1}$ Department of Pharmacology \\ ${ }^{2}$ Graduate School of Biomedical Sciences \\ ${ }^{3}$ Department of Psychiatry \\ Korea University College of Medicine \\ Seoul 136-705, Korea \\ ${ }^{4}$ Corresponding author: Tel, 82-2-920-6195; \\ Fax, 82-2-927-0824; E-mail, kyungho@korea.ac.kr
}

Accepted 15 December 2005

Abbreviations: BDNF, brain-derived neurotrophic factor; BrdU, bromodeoxyuridine; CMS, chronic mild stress; GCL, granule cell layer; SGZ, subgranular zone

\footnotetext{
Abstract

New-born cells continue to proliferate and survive to become mature granule cells in adult rat hippocampus. Although this process, known as neurogenesis, is inhibited by acute stress, it is not clear whether chronic stress affects neurogenesis. To determine whether chronic mild stress (CMS) influ ences neurogenesis in the adult rat hippocampus, male Sprague-Dawley rats were exposed to CMS and administered bromodeoxyuridine (BrdU) before or after CMS to observe the survival/differentiation or proliferation of new-born cells, respectively. In addition, we measured brain-derived neurotrophic factor (BDNF) mRNA in the granule cell layer (GCL) of the hippocampus, because BDNF is known to play an important role in the survival of new-born cells. CMS significantly decreased the survival of newborn cells in the GCL, but did not influence the proliferation or differentiation of new-born cells. CMS did not affect the proliferation and survival of new-born cells in the hilus. In addition, CMS did not change BDNF mRNA levels in the GCL. These results demonstrate that CMS reduces the survival of new-born cells but not of their proliferation, suggesting that repeated mild stress could influence
}

a part of neurogenesis, but not the whole part of neurogenesis. These results raise the possibility that the survival of new-born cells may be suppressed in the presence of normal BDNF mRNA levels in GCL.

Keywords: brain-derived neurotrophic factor; bromodeoxyuridine; depression; hippocampus; neurogenesis; stress

\section{Introduction}

The adult mammalian brain is capable of neurogenesis throughout life, but this is restricted to two major regions in brain: the olfactory bulb and the hippocampus (Cameron et al., 1994; Gould et al., 2002). A substantial number of new-born cells in subgranular zone (SGZ) of the hippocampus continue to divide and migrate into the granule cell layer (GCL) where they mature into neurons or astrocytes. Hippocampal neurogenesis can be influenced by several environmental factors. It has been demonstrated that stress reduces new-born cell proliferation in the hippocampus (Gould et al., 1997; Tanapat et al., 1998), whereas treatment with chronic antidepressants increases proliferation (Malberg et al., 2000; Duman et al., 2001). As a result, repeated stress may contribute to the reduction in hippocampal volume reported in patients with depression (Bremner et al., 2000) in part through reduced neurogenesis in the hippocampus, which could be prevented by chronic antidepressant treatment (Czeh et al., 2001; Li et al., 2004).

Neurogenesis regulation could occur at several different levels, e.g., by cell proliferation, differentiation, or survival. Several factors play a role in the regulation of neurogenesis, and in particular, neurotrophic factors are known to be critical for the survival of new-born cells during their development in vivo and in culture (Palmer et al., 1997). Among the factors that are involved in neural and glial differentiation (Aberg et al., 2000; Lee et al., 2003; Kim et al., 2004), brain-derived neurotrophic factor (BDNF) is interesting, because it has been shown to promote the differentiation and survival of progenitor cells in the adult brain (Zigova et al., 1998), and in cultured cells (Vicario-Abejon et al., 1995; Palmer et al., 1997). In addition, singing behavior has also been reported to increase the expression of BDNF, and this was also found to be correlated with the extent of new 
Table 1. Schedule of chronic mild stress.

\begin{tabular}{clllll}
\hline & Monday & Tuesday & Wednesday & Thursday & Friday \\
\hline Morning & Restraint $1 \mathrm{~h}$ & Restrain $\mathrm{t} 1 \mathrm{~h}$ & $\begin{array}{l}\text { Access to } \\
\text { restricted food } \\
(3 \mathrm{~g}) \text { for } 2 \mathrm{~h}\end{array}$ & $\begin{array}{l}1 \mathrm{~h} \text { exposure to } \\
\text { empty bottle: } \\
\text { restraint } 1 \mathrm{~h}\end{array}$ & Restraint $1 \mathrm{~h}$ \\
Afternoon & $\begin{array}{l}\text { Restraint } 1 \mathrm{~h}, \\
\text { overnight } \\
\text { illumination }\end{array}$ & $\begin{array}{l}\text { Restraint } 1 \mathrm{~h}, \\
\text { overnight food } \\
\text { and water } \\
\text { deprivation }\end{array}$ & $\begin{array}{l}\text { Restraint } 1 \mathrm{~h}, \\
\text { overnight water } \\
\text { deprivation }\end{array}$ & $\begin{array}{l}\text { Restraint } 1 \mathrm{~h}, \\
\text { group-housed in } \\
\text { soiled cage } \\
\text { overnight }\end{array}$ & $\begin{array}{l}\text { Reversed } \\
\text { light-dark cycle } \\
\text { throughout the } \\
\text { weekend }\end{array}$ \\
\hline
\end{tabular}

neuron survival (Li et al., 2000).

It has been demonstrated that chronic stress decreases the proliferation and survival of new-born neurons in the SGZ of the adult tree shrew (Gould et al., 1997). Moreover, exposure to fox odor was found to inhibit new-born cell proliferation in the hippocampus of adult rats, and this was found to be dependent on stress-induced corticosterone increases (Tanapat et al., 2001). Consistent with these findings, systemic treatment with corticosterone was found to reduce new-born cell proliferation (Cameron et al., 1994). Although acute stress was found to decrease new born-cell proliferation (Tanapat et al., 2001; Kim et al., 2005), it remains unclear as to whether chronic stress influences neurogenesis in the adult rat hippocampus. In the present study, we examined the effects of chronic mild stress (CMS) on the proliferation, differentiation, and survival of new-born cells in the adult rat hippocampus. CMS is one of the validated animal models that imitates anhedonia (one of the two core symptoms in patients with depression) (Stout et al., 2000). In the present study, rats were given bromodeoxyuridine (BrdU) as a marker of mitotic cells before and after CMS to allow the determination of the survival/differentiation and proliferation of new-born cells in hippocampus, respectively. In addition, we examined the effects of CMS on the expression of BDNF mRNA in the hippocampus.

\section{Materials and Methods}

\section{Animals and chronic mild stress exposure}

Male Sprague-Dawley rats (initial weight, 150-180 g; $n=6$ per group, Samtaco, Osan, Korea) were received $7 \mathrm{~d}$ before initiating the CMS procedures, and were housed three per cage under a $12 \mathrm{~h}$ lightdark cycle (lights on at 6:00 A.M.). Food and water were available ad libitum except during the food and/or water deprivation periods of the CMS procedures. Rats were exposed to CMS for $19 \mathrm{~d}$ from Monday morning, which consisted of the adminis- tration of various stressors, as previously described (Moreau et al., 1996; Di Chiara et al., 1999). The stressors included repeated $1 \mathrm{~h}$ periods of confinement to a small cage $(24 \times 10 \times 9 \mathrm{~cm})$, one period of continuous overnight illumination, one overnight period of food and water deprivation followed by $2 \mathrm{~h}$ of access to restricted food ( $3 \mathrm{~g}$ per cage), one overnight period of water deprivation followed by $1 \mathrm{~h}$ exposure to an empty bottle, one overnight period of group housing ( 6 rats per cage) in a soiled cage $(200 \mathrm{ml}$ of water in sawdust bedding). Animals were also maintained on a reversed light/dark cycle at weekends from Friday (5:00 P.M.) to Monday morning (9:00 A.M.) (Table 1). The last CMS procedure consisted of a reversed light/dark cycle on 19th d (from 5:00 P.M. on the Friday to lights on at 6:00 A.M. on the Saturday). Lights in the animal room were not turned off on this Saturday morning after completing this last CMS procedure. Nonstressed control rats were housed in a separate room and were briefly handled each day without restraint. All procedures used in this study were consistent with the National Institutes of Health Guide for the Care and Use of Laboratory Animals (Institute of Laboratory Animal Resources, 1996).

\section{BrdU treatment}

To determine the effect of CMS on cell survival and differentiation, BrdU (Sigma, St. Louis; in 0.9\% saline with $0.007 \mathrm{~N} \mathrm{NaOH}$ ) was injected intraperitoneally at $4 \times 75 \mathrm{mg} / \mathrm{kg}$ every $2 \mathrm{~h}$, and $18 \mathrm{~h}$ after the last BrdU injection, rats were exposed to the CMS procedures for 19 d. CMS-exposed rats were perfused at 6-8 $\mathrm{h}$ after last CMS procedure, and control animals were perfused midway through the sacrificing of the CMS-exposed rats to reduce time of sacrifice differences. At this survival time, labeled cells had extended axons (Hastings et al., 1999), survived a period of cell death (Gould et al., 1999), and had begun to express mature neuronal markers (Cameron et al., 1993). To measure the effect of 


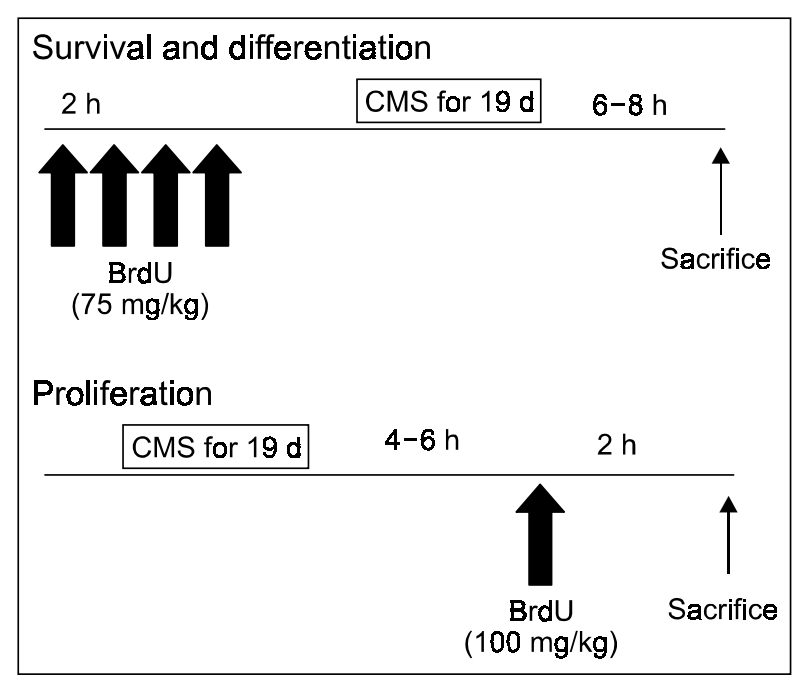

Figure 1. Bromodeoxyuridine ( $\mathrm{BrdU})$ treatment. To measure the effect of chronic mild stress (CMS) on cell survival, BrdU $(75 \mathrm{mg} / \mathrm{kg} \times$ 4 , every $2 \mathrm{~h}$ ) was given $18 \mathrm{~h}$ before the CMS procedures. Rats were subjected to the CMS procedures for $19 \mathrm{~d}$ and were perfused 6-8 $\mathrm{h}$ after the final CMS stressor. To examine the influence of CMS on the proliferation of BrdU-labeled cells, animals underwent CMS for $19 \mathrm{~d}$ and were then given a single dose of $\operatorname{BrdU}(100 \mathrm{mg} / \mathrm{kg})$ 4-6 $\mathrm{h}$ after the final CMS stressor. Animals were sacrificed $2 \mathrm{~h}$ after BrdU administration.

CMS on cell proliferation, rats exposed to CMS were given a single injection of $\mathrm{BrdU}(100 \mathrm{mg} / \mathrm{kg}$, i.p.) at 4-6 $\mathrm{h}$ after the last CMS procedure and were then perfused $2 \mathrm{~h}$ later (Figure 1). The $2 \mathrm{~h}$ survival time allowed for the incorporation of BrdU into cells due to DNA synthesis, and provided an index of the rate of cell birth at specific times after stress, but not for the completion of mitosis (Nowakowski et al., 1989) or migration (Cameron et al., 1993).

\section{Histological procedure}

Rats were anesthetized with sodium pentobarbital (100 $\mathrm{mg} / \mathrm{kg}$, i.p.) and perfused intracardially with $0.9 \%$ saline, followed by $4 \%$ paraformaldehyde in $0.1 \mathrm{M}$ sodium phosphate buffer, pH 7.2 (PPB). Brains were then removed, post-fixed for $12 \mathrm{~h}$, and placed in $20 \%$ sucrose/PPB overnight at $4^{\circ} \mathrm{C}$. Serial coronal sections $(40 \mu \mathrm{m})$ were prepared through the hippocampus (bregma $-2.12 \mathrm{~mm}$ to $-6.30 \mathrm{~mm}$, (Paxinos et al., 1997)) using a freezing microtome (Microm International GMBH, Walldorf, DRG), and stored in a cryoprotectant at $-20^{\circ} \mathrm{C}$ until required. Every sixth section was incubated with $0.6 \% \mathrm{H}_{2} \mathrm{O}_{2}$ in phosphatebuffered saline (PBS) for $30 \mathrm{~min}$ to block endogenous peroxidase. To denature DNA, sections were incubated in $50 \%$ formamide $/ 50 \% 2 \times$ SSC at $65^{\circ} \mathrm{C}$ for $2 \mathrm{~h}$, rinsed in $2 \times \mathrm{SSC}$ for $5 \mathrm{~min}$, and then incubated in $2 \mathrm{~N} \mathrm{HCl}$ at $37^{\circ} \mathrm{C}$ for $30 \mathrm{~min}$. Sections were then rinsed for $10 \mathrm{~min}$ in $0.1 \mathrm{M}$ sodium borate $(\mathrm{pH} 8.5)$, washed with PBS, and incubated for $1 \mathrm{~h}$ in PBS containing $0.3 \%$ Triton $\mathrm{X}-100$ (PBS-T) followed by $3 \%$ normal horse serum at room temperature for $2 \mathrm{~h}$. Thereafter, sections were incubated in monoclonal mouse anti-BrdU antibody (1:500, Roche Diagnostics $\mathrm{GmbH}$, Mannheim, DRG) for $72 \mathrm{~h}$ at $4^{\circ} \mathrm{C}$, followed by biotinylated horse anti-mouse $\lg G$ (1:500, Vector Laboratories, Burlingame) overnight at $4^{\circ} \mathrm{C}$. After several rinses with PBS-T, the sections were incubated in avidin-biotin-peroxidase complex (1:500, Vector Laboratories) for $3 \mathrm{~h}$ at room temperature. Finally, they were incubated in diaminobenzidine solution containing nickel chloride for $10 \mathrm{~min}$, rinsed with PBS, mounted on glass slides, and dried overnight. The slides were counterstained with hematoxylin, dehydrated, and cover-slipped with Permount.

\section{Double-Immunofluorescence}

To determine the phenotype of progenitor cells in adult rat hippocampus, double immunofluorescence was conducted to detect the colocalization of BrdU with either calbindin D28k or glial fibrillary acidic protein (GFAP). Calbindin D28k (Kempermann et al., 1997) and GFAP (Cameron et al., 1993) have been used as markers of mature granule neurons and astroglia, respectively. For the fluorescence immunolabeling of phenotypic markers, sections were pretreated as described above, and blocked with $5 \%$ normal donkey serum (Jackson Immuno Reaserch, West Grove) in PBS containing 0.3\% Triton X-100 (PBS-T) for $1 \mathrm{~h}$ at room temperature. After washing in PBS-T, sections were incubated in primary antibody cocktail [either in BrdU (monoclonal, Roche Diagnostics) and calbindin D28k (polyclonal, Chemicon, Temecula), or in BrdU and GFAP (polyclonal, Santa Cruz Biotechnology, Santa Cruz)] for $4 \mathrm{~d}$ at $4^{\circ} \mathrm{C}$. For BrdU and calbindin D28k double labeling, sections were incubated overnight at $4^{\circ} \mathrm{C}$ in a cocktail of secondary antibodies [FITC conjugated donkey anti-mouse IgG (Jackson Immuno Research) for BrdU, and rhodamine red-X conjugated donkey anti-rabbit IgG (Jackson Immuno Research) for calbindin D28k]. For BrdU and GFAP double labeling, sections were incubated overnight at $4{ }^{\circ} \mathrm{C}$ in a cocktail of secondary antibodies [FITC conjugated donkey anti-mouse IgG (Jackson Immuno Research) for BrdU, and then incubated with rhodamine red-X conjugated streptavidin (Jackson Immuno Research) for rabbit anti-GFAP (Santa Cruz Biotechnology) for $3 \mathrm{~h}$ at room temperature. After a rinse in $4 \mathrm{mM}$ sodium carbonate buffer for $15 \mathrm{~min}$ at room temperature, sections were washed, and mounted and coverslipped with Gel-Mount (Biomeda, Foster City). 


\section{Data analysis}

In sections processed for BrdU immunohistochemistry alone, staining and cell counting was repeated in two series. All BrdU-labeled cells including individual cells within a cluster, were counted regardless of size or shape on every 12th section throughout the hippocampus (bregma $-2.12 \mathrm{~mm}$ to $-6.30 \mathrm{~mm}$, (Paxinos et al., 1997)), excluding cells located in the outermost plane of focus, using a light microscope (Nikon Alphaphot-2). Since many SGZ BrdUlabeled cells were found in clusters, individual cells were counted at high magnification $(400 \times$ or 1,000 $\times)$. SGZ BrdU-labeled cells that were within two cell body widths of the GCL were considered part of the GCL. Cells that were located more than two cells away from the GCL were classified as being located in the hilar region. For each series, total numbers of GCL and hilar BrdU-labeled cells were multiplied by 12 to obtain an estimate of the total number of BrdU-labeled cells per region. Values for repetitions were averaged. GCL and hilar cell counts were summed to give the total cell number in the dentate gyrus. To determine GCL cross-sectional areas, counterstained GCL was outlined at a magnification of $\times 100$ and areas were measured using the NIH image analysis program (version 1.61). For sections processed for combined immunofluorescence labeling, anatomically matched sections (bregma -3.60 to $-3.80 \mathrm{~mm}$ ) from each brain were analyzed. Immunofluorescence was detected and processed using a confocal laser scanning microscope (Olympus IX70) fitted with an $\times 20$ objective. At least 50 BrdU-positive cells per animal were analyzed using Z-plane sectioning $(1 \mu \mathrm{m})$ to confirm the colocalization of BrdU with phenotype-specific markers. Because BrdU-labeled cells in the hilus rarely express calbindin D28k or GFAP, the numbers of BrdU-labeled cells in GCLs, including the SGZ, that were immunoreactive for either calbindin D28k or GFAP were determined (Tanapat et al., 1999). A minimum of 50 BrdU-labeled cells were measured per brain, and numbers of double-labeled cells were expressed as percentages of the total number of BrdU-labeled cells. Data are expressed as means \pm SEM and subjected to the Student's $t$-test. Significance was accepted at the $P<0.05$ level.

\section{In situ hybridization}

Brain tissue sections stored in 4\% paraformaldehyde/ $0.1 \mathrm{M}$ phosphate buffer were transferred into a plastic mesh in a 12-well culture plate. The sections were permeabilized with proteinase $\mathrm{K}\left(1 \mu \mathrm{g} / \mathrm{ml}, 37^{\circ} \mathrm{C}, 30\right.$ $\mathrm{min})$, treated with acetic anhydride in $0.1 \mathrm{M}$ triethanolamine $(\mathrm{pH} 8.0)$, washed in $2 \times \mathrm{SSC}(\mathrm{pH} 7.0)$, and then transferred into $500 \mu$ of hybridization solution in a 24-well culture plate. The hybridization buffer consisted of $50 \%$ formamide, $0.01 \%$ polyvinyl pyrrolidone, $0.01 \%$ Ficoll, $0.01 \%$ bovine serum albumin, $50 \mu \mathrm{g} / \mathrm{ml}$ denatured salmon sperm DNA, 250 $\mu \mathrm{g} / \mathrm{ml}$ yeast tRNA, $40 \mathrm{mM}$ dithiothreitol, $10 \%$ dextran sulfate, and 35S-labeled BDNF cRNA probes at 1 $\times 10^{7} \mathrm{cpm} / \mathrm{ml}$. The sections were hybridized freefloating for $18 \mathrm{~h}$ at $55^{\circ} \mathrm{C}$ in hybridization solution. After overnight incubation, sections were rinsed for $2 \times 30 \mathrm{~min}$ at $55^{\circ} \mathrm{C}$ in $4 \times \mathrm{SSC}$ with $5 \mathrm{mM}$ DTT, treated with RNase A $\left(20 \mu \mathrm{g} / \mathrm{ml}, 30 \mathrm{~min}\right.$ at $\left.45^{\circ} \mathrm{C}\right)$, washed for $4 \times 15 \mathrm{~min}$ in $2 \times \mathrm{SSC}$ containing 5 $\mathrm{mM}$ DTT at room temperature. They were then rinsed for $2 \times 30 \mathrm{~min}$ in $0.5 \times \mathrm{SSC}$ containing $5 \mathrm{mM}$ DTT, once for $30 \mathrm{~min}$ in $0.1 \times \mathrm{SSC}$ containing $5 \mathrm{mM}$ DTT at $50-55^{\circ} \mathrm{C}$, and once in $0.1 \times$ SSC containing 5 $\mathrm{mM}$ DTT at room temperature. Sections were mounted onto gelatin-coated microscope slides, and air-dried overnight. They were then exposed to Hyperfilm $\beta$-max (Amersham Biosciences, Piscataway) for 3-5 d. Levels of BDNF mRNA were determined by outlining regions of interest on in situ hybridization section images and by quantifying densitometrically using an $\mathrm{NIH}$ image analysis program (version 1.61). Optical densities were obtained from each hippocampus subfield defined using a stereotaxic atlas (Paxinos et al., 1997). To correct for nonlinearity, ${ }^{14} \mathrm{C}$ labeled radioactive standards (Amersham Biosciences, Piscataway) were exposed with tissue sections for calibration purposes. Results are expressed as means \pm SEM. Data were subjected to Student's $t$-test and significance was accepted at the $P<0.05$ level.

\section{Results}

\section{The effects of CMS on the proliferation of new-born cells in the adult rat hippocampus}

To determine whether CMS induces changes in newborn cells in the adult rat hippocampus, rats exposed to CMS for $19 \mathrm{~d}$ were given a single injection of BrdU 4-6 $\mathrm{h}$ after the final CMS procedure, and then sacrificed $2 \mathrm{~h}$ later. BrdU-labeled cells were found to be localized exclusively near the SGZ (the border between the GCL and the hilus) of the hippocampus (Figure 2A). These cells were darkly stained and irregularly shaped, and were found in clusters (Figure 2B). CMS-exposed rats showed no difference from control rats in terms of the number of BrdU-labeled cells in the GCL, hilus, or dentate gyrus (Figure 3 and 5). Moreover, no apparent differences in gross morphology and location of these cells were observed within the GCL (control: 78.9\%; CMS: 82.9\%) or hilus (control: 21.1\%; CMS: $17.1 \%$ ) between control and CMS-exposed rats. 

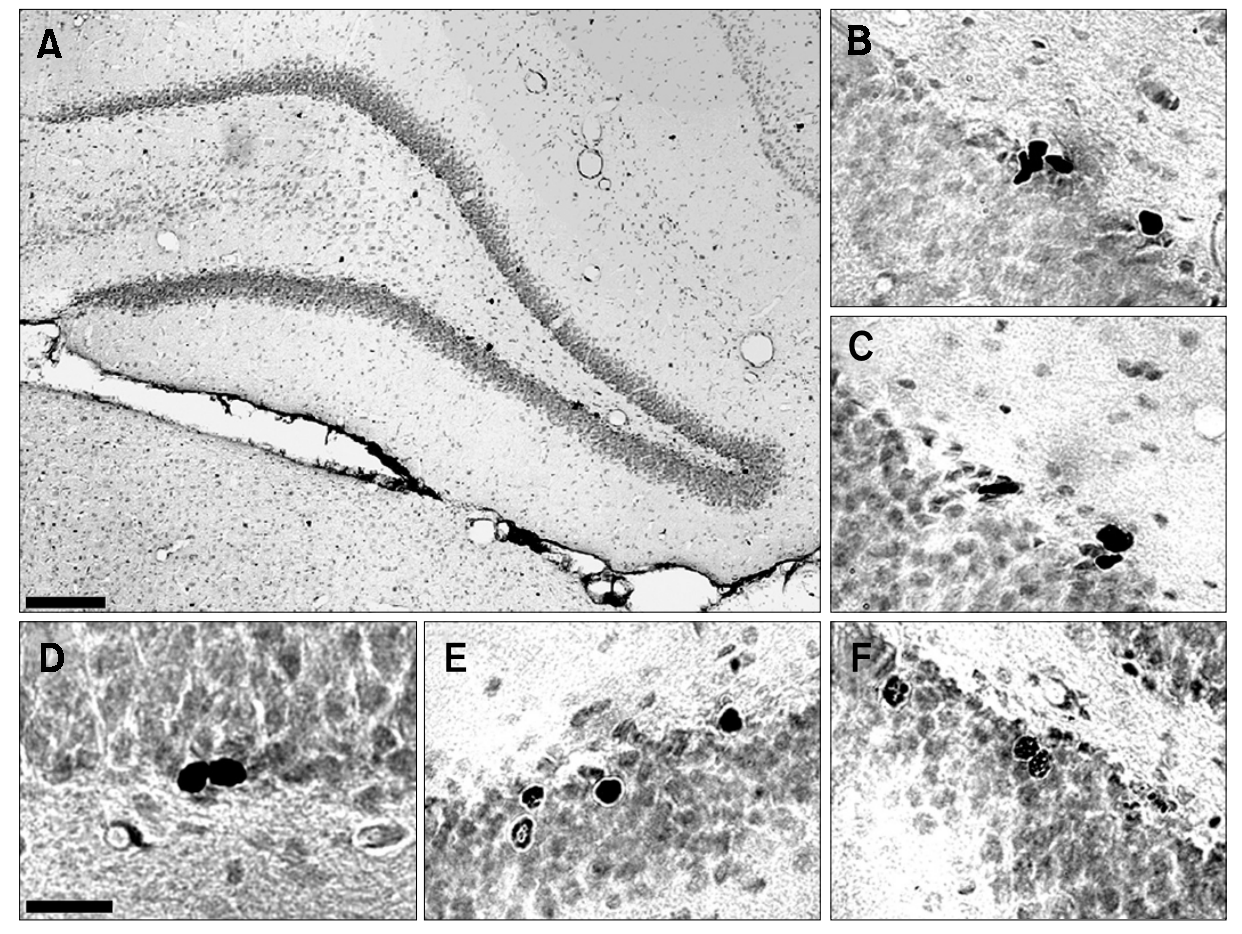

Figure 2. BrdU immunohistochemistry. (A) Shortly after the proliferation stage $(2 \mathrm{~h}$ after $\mathrm{BrdU}$ injection) BrdU-labeled cells were localized to the subgranular zone (SGZ) between granule cell layer (GCL) and hilus, and were often found in clusters (B). At this stage, the nuclei of BrdU-labeled cells were dark and irregular in shape (C). Mitotic figures were also evident (D). In contrast, BrdU-labeled cells $20 \mathrm{~d}$ after BrdU injection showed mature granule cell morphology within the GCL with dark, uniform BrdU-labeled nuclei (E) or sparse, multipunctate BrdU-labeled nuclei $(F)$. Scale bar $=200 \mu \mathrm{m}$ for A, $20 \mu \mathrm{m}$ for B-F.

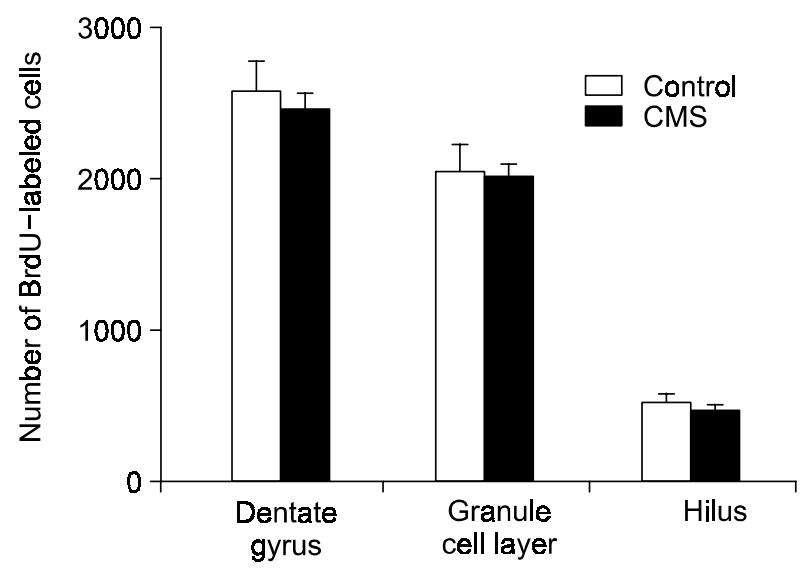

Figure 3. Effects of CMS on new-born cell proliferation in the adult rat hippocampus. CMS exposed rats received a single BrdU injection 4-6 $\mathrm{h}$ after the last CMS procedure and were sacrificed $2 \mathrm{~h}$ later. The results shown are the means \pm SEM of BrdU-labeled cells in subregions of the hippocampus ( $n=6$ per group). CMS did not affect new-born cell proliferation in the adult rat hippocampus comparing to the control.

\section{The effects of CMS on the survival of new-born cells in the adult rat hippocampus}

To determine whether CMS affects the survival of cells that have already been born in the hippocampus, rats were given four injections of $\mathrm{BrdU}$ (4 $\times 75 \mathrm{mg} / \mathrm{kg}$, i.p.) and then subjected to CMS for $19 \mathrm{~d}$. Rats were sacrificed $6-8 \mathrm{~h}$ after the last CMS

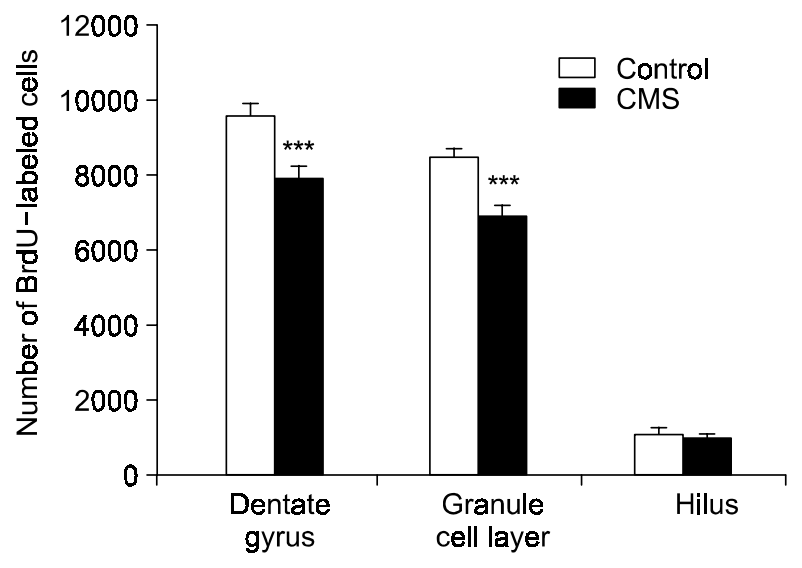

Figure 4. Effects of CMS on the survival of new-born cells in the adult rat hippocampus. Rats received BrdU injections $18 \mathrm{~h}$ before CMS and were euthanized 6-8 $\mathrm{h}$ after the last CMS procedure. The results shown are means \pm SEM of BrdU-labeled cells in subregions of the hippocampus ( $n=6$ per group). Rats subjected to CMS showed a significant decrease in the survival of new-born cells in the dentate gyrus and in GCL relative to control rats. ${ }^{* * *} P<0.01$ significantly different from control rats.

procedure. Microscopic analysis showed that many BrdU-labeled cells were located in the GCL and that they were indistinguishable in terms of morphology from neighboring granule cells. Some BrdU-labeled cells were round with uniform BrdU nuclear staining throughout the nucleus, whereas other nuclei had a punctate or spotted appearance (Figure 2E and 


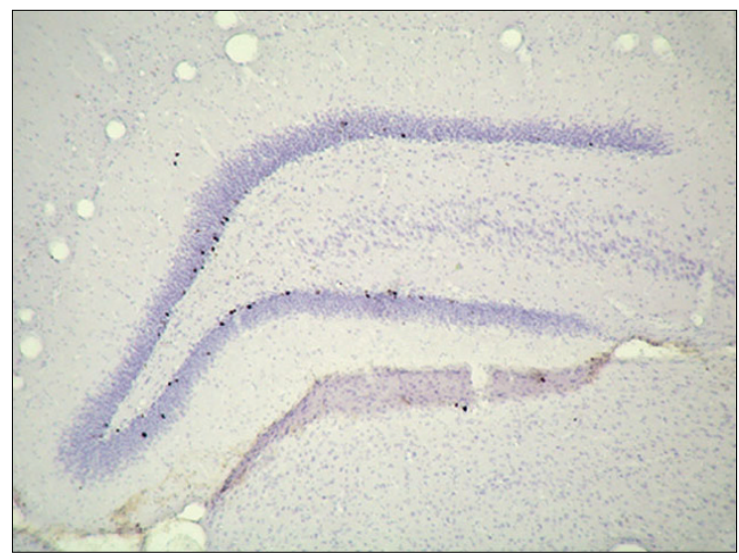

CON + SUR

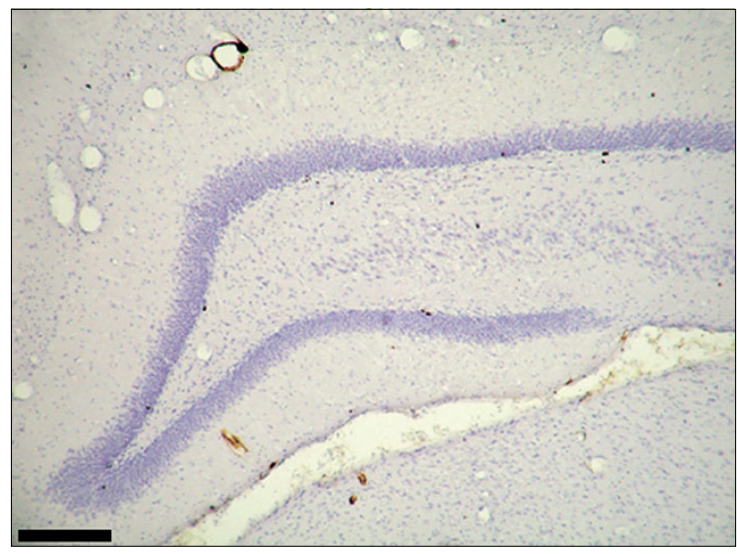

CON + PRL

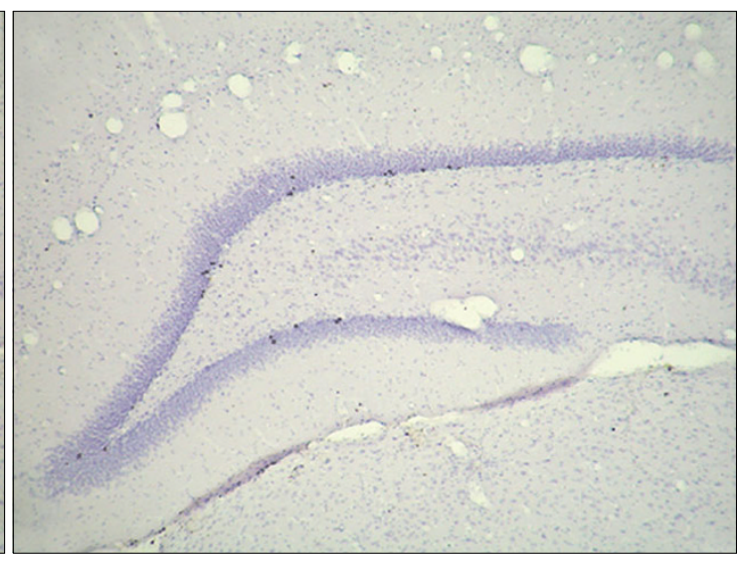

CMS + SUR

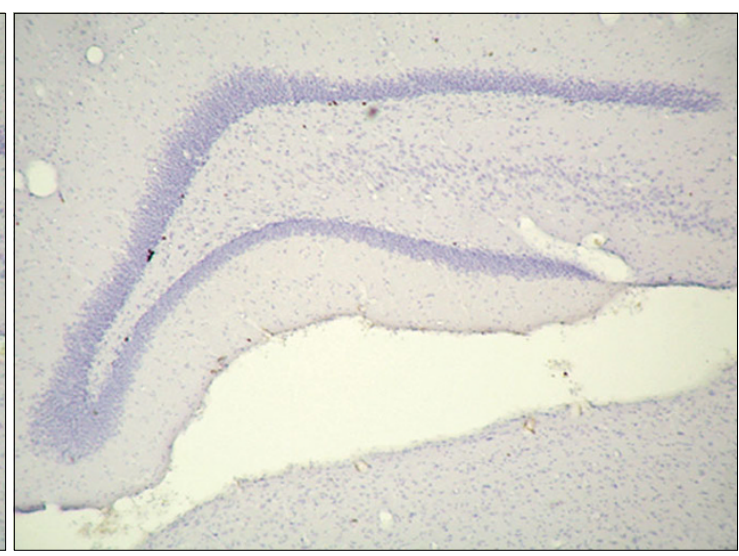

CMS + PRL

Figure 5. Representative photomicrographs of neurogenesis in the adult rat hippocampus ( $400 \times$ magnification). The survival of new-born cells in the hippocampus was significantly reduced by CMS compared to the control. Abbreviations used: CON + SUR: control-survival; CMS + SUR: CMS-survival; CON + PRL: control-proliferation; CMS + PRL: CMS-proliferation. Scale bar $=200 \mu \mathrm{m}$.

F). No clusters of BrdU-labeled cells were found at this time. CMS significantly decreased the number of BrdU-labeled cells by $\sim 20 \%$ in the dentate gyrus and $\mathrm{GCL}$ relative to the control (dentate gyrus: control, $9542 \pm 357$ (mean \pm SEM); CMS, $7843 \pm$ $394(P<0.01)$; GCL: control, $8450 \pm 256$; CMS, $6842 \pm 336(P<0.01))$ (Figure 4 and 5). In contrast, no difference in the number of BrdU-labeled cells was observed within the hilus in CMS-exposed and control rats (Figure 4). However, BrdU-labeled cells in CMS-exposed and control rats did not apparently differ in terms of morphology or location within the GCL or hilus (Figure 6A). These results suggest that CMS selectively suppresses the survival of newborn cells in adult rat hippocampus, but not cell proliferation, relative to control. To determine whether CMS may influence hippocampal volumes, GCL cross-sectional areas were measured. These crosssectional areas were not significantly different be- tween control and CMS-exposed rats (Figure 6B). Although GCL cross-sectional area does not reflect the exact changes in volume, this finding raises the possibility that CMS may not be sufficient or strong enough to change the GCL volume of hippocampus.

\section{The effects of CMS on cellular phenotype in the adult rat hippocampus}

To determine the phenotype of mature BrdU-labeled cells, sections were double-labeled for BrdU and for calbindin D28k or GFAP. Confocal microscopy, using z-plane sections to confirm individual cell colocalizations, revealed that $\sim 80 \%$ of BrdU-labeled cells in GCL were immunoreactive for calbindin D28k $(82.3 \pm 1.4$ and $84.6 \pm 2.6 \%$ for control and CMSexposed rats, respectively; Figure $6 \mathrm{C}$ and $7 \mathrm{~A}$ ), and that $\sim 15 \%$ of BrdU-labeled cells colocalized with GFAP $(13.8 \pm 2.1$ and $14.4 \pm 1.8 \%$ for control and 
A

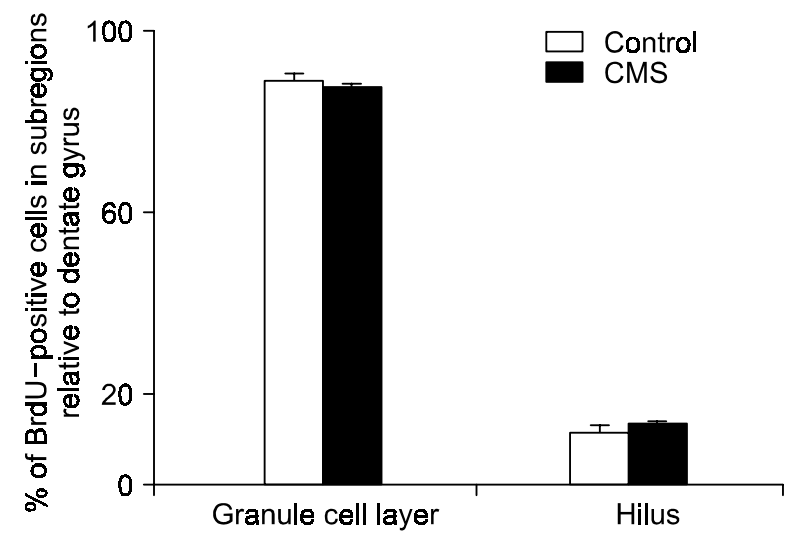

C

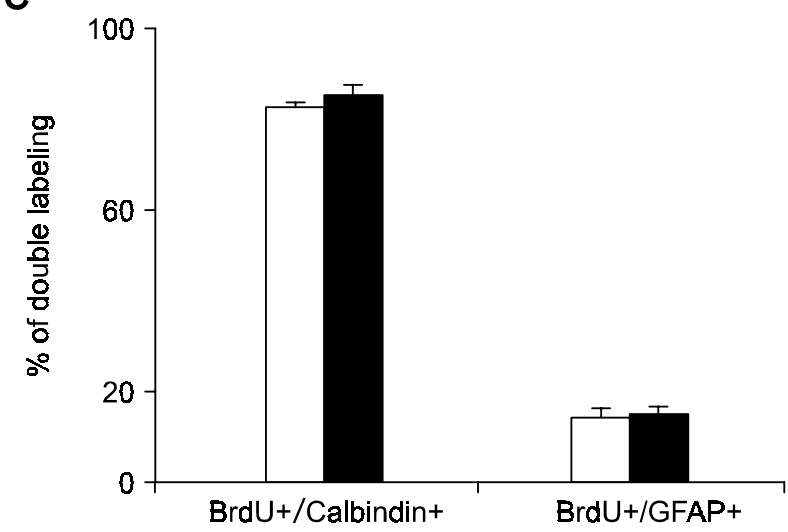

B $\left(10^{5} \mu \mathrm{m}^{2}\right)$

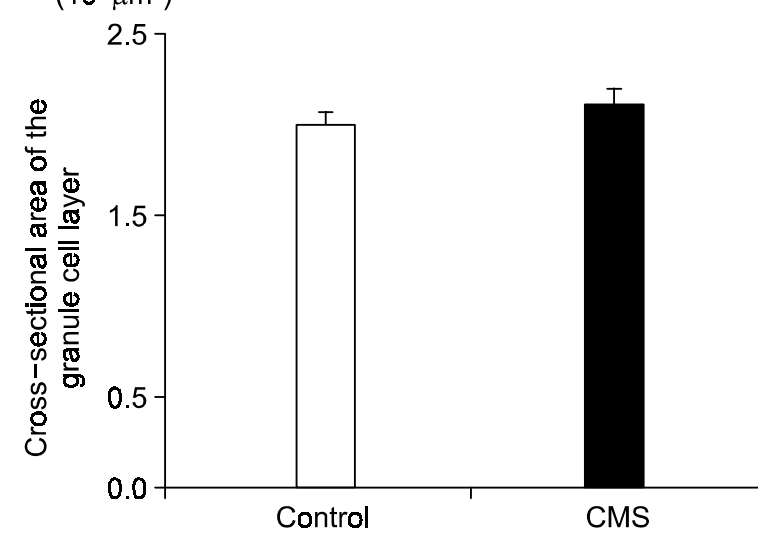

D

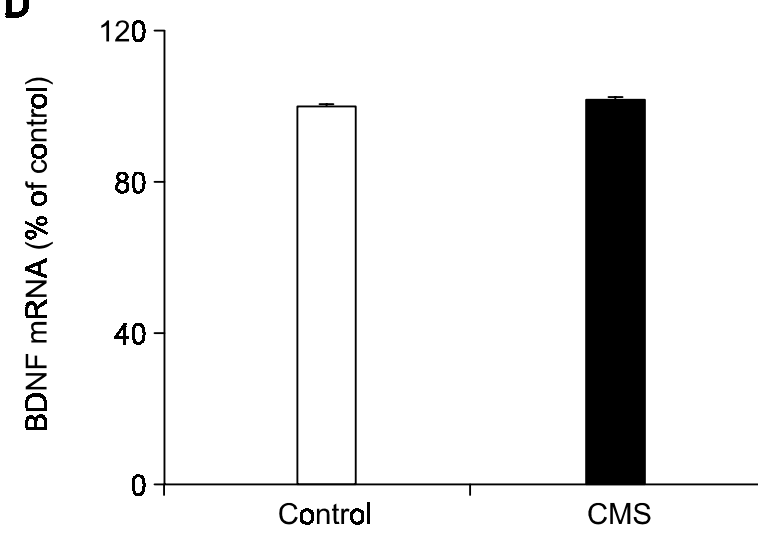

Figure 6. Locations of BrdU-labeled cells within the GCL and hilus at $20 \mathrm{~d}$ after BrdU injection. (A) The location of BrdU-labeled cells within $\mathrm{GCL}$ or hilus at $20 \mathrm{~d}$ after BrdU injection was not changed by CMS (filled bar) compared to the control (open bar). (B) GCL cross sectional areas were not significantly different between CMS exposed and control rats. (C) The percentages of BrdU-labeled cells that were immunoreactive for calbindin D28k or GFAP in the hippocampus GCL were similar for CMS exposed and control rats. (D) CMS did not change BDNF mRNA levels in GCL compared to the control.

CMS-exposed rats, respectively, Figure 6C). The percentage of BrdU-labeled cells that were immunoreactive for either calbindin D28k or GFAP did not differ in control and CMS-exposed rats, indicating that differentiation into either neurons or astroglia may not be affected by CMS. However, it should be mentioned that we selected $\sim 50$ BrdU-positive cells in hippocampus per animal to determine the phenotype of BrdU-labeled cells. Thus, it appears that CMS might have not influenced the differentiation of survived cells, although it decreased the survival of new-born cells in hippocampus.

The effects of CMS on BDNF mRNA expression in the adult rat hippocampus

BDNF has been reported to be important for neuronal survival during development. Moreover, the expression of BDNF in the hippocampus is known to be down-regulated in response to acute or repeated stress, which raises the possibility that a stress induced decrease in BDNF mRNA expression in the hippocampus may contribute to the suppression of the survival of new-born cells in response to CMS. In the present study, CMS did not change the BDNF mRNA levels in GCL (Figure 6D and 7A), indicating that the applied CMS may not be sufficient to reduce BDNF mRNA expression in the GCL.

\section{Discussion}

In the present study, to observe the effects of CMS on the survival of new-born cells, BrdU was administered before CMS exposure, and the number of BrdU-labeled cells was determined $19 \mathrm{~d}$ later. Under these conditions, the survival of BrdU-labeled cells can be determined independently of the influence 

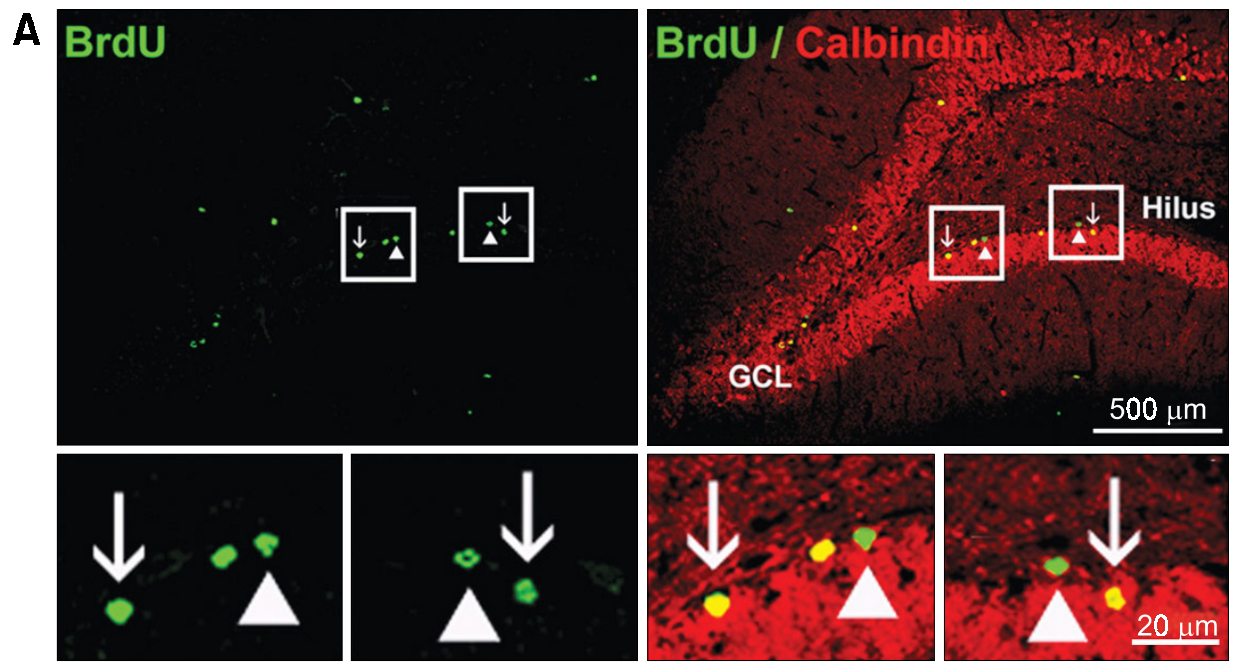

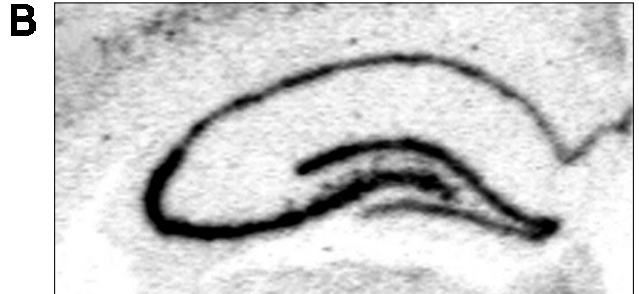

Control

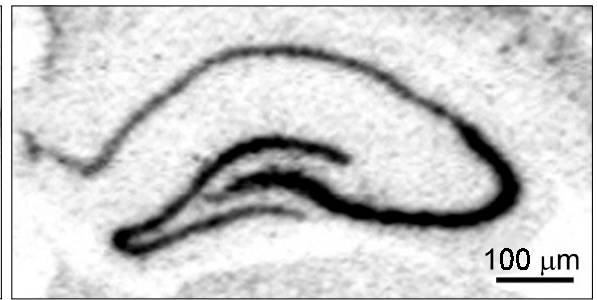

CMS
Figure 7. (A) Confocal scanning laser images of sections labeled by BrdU (upper left and lower left, green) and double labeled by BrdU and calbindin D28k, a marker of mature neuron (upper right, red). Arrows indicate neurons which are both BrdU- and Calbindin-positive (lower right, yellow stained). Arrowheads show BrdU-labeled cells, which do not express calbindin D28k. (B) Representative autoradiographs of BDNF mRNA levels in the hippocampus of rats exposed to chronic mild stress (CMS) or brief handling (nonstressed control). of CMS on cell proliferation. The results of the present study demonstrate that CMS reduces the survival of new-born cells in the GCL and dentate gyrus of the adult rat hippocampus. However, in contrast to the reduced survival of new-born cells in the GCL in response to CMS, no difference in proliferation of new-born cells was seen between control and CMS-exposed rats, suggesting that CMS selectively suppress the survival of new-born cells in the hippocampus, but not their proliferation.

Previous studies have shown that acute (Tanapat et al., 1998) and chronic psychosocial stress (Gould et al., 1997) reduces granule cell proliferation. In the present study, the numbers of BrdU-labeled cells in the GCL and dentate gyrus of rats exposed to CMS were similar to those of controls, indicating that CMS did not influence new-born cell proliferation. This result differs from those of previous studies, which showed reduced granule cell proliferation in response to acute (Tanapat et al., 1998) and chronic psychosocial stress (Gould et al., 1997). However, the present study and these previous reports differ fundamentally e.g., in terms of type of stress, species used, and experimental animal age. We measured plasma corticosterone 6-8 $\mathrm{h}$ after the last CMS procedure, but we could not find any significant changes in plasma corticosterone levels between the CMS-exposed rats and nonstressed controls (data not shown). This plasma corticosterone result is in agreement with a previous report, which found that the same procedures of CMS did not change the serum levels of ACTH or corticosterone (Stout et al., 2000). Thus, if cell proliferation in the adult rat hippocampus is regulated by plasma corticosterone (Cameron et al., 1994), it appears that no significant change would be expected in cell proliferation in rats exposed to CMS. Interestingly, the present results raise the possibility of a habituation of the hypothalmo-pituitaryadrenal (HPA) axis in response to repeated mild stress. The habituation of HPA axis activation has been previously shown after repeated exposure to restraint (Hauger et al., 1990; Cole et al., 2000), cold (Bhatnagar et al., 1995), noise (Armario et al., 1986), water immersion (De Boer et al., 1990), and repeated handling (Dobrakovova et al., 1993).

Interestingly, CMS selectively decreased the survival of new-born cells in GCL and dentate gyrus of the adult rat hippocampus in the present study. The survival of new-born cells in hippocampus has been reported to be influenced by many factors including glucocorticoid and neurotrophins. Prolonged hypothalamo-pituitary-adrenal (HPA) axis activation and the resulting elevation of circulating glucocorticoid levels, observed during stress and aging, have been reported to produce cell death in the hippocampus (Sapolsky, 1996) and evidence conti- 
nues to suggest that glucocorticoid-induced neuronal death in all these physiological and pathophysiological settings occurs by apoptosis (Reagan et al., 1997). Moreover, it was reported that BrdU-labeled cells peak at around one week following BrdU injection and then decline over one or two weeks (Gould et al., 1999), but no further decrease in BrdUlabeled cells was subsequently observed (Hastings et al., 1999). Thus, it is possible that glucocorticoid levels were elevated during the early stages of CMS, but not enough to induce habituation during the procedures of CMS, which could lead to suppression of the survival of new-born cells in the adult rat hippocampus. In the present study, we measured plasma corticosterone levels only after CMS procedures, but not during the CMS procedures. It is not clear whether CMS preferentially increases plasma corticosterone during the early stages of CMS despite normal serum levels of ACTH or corticosterone after the same CMS procedures, (Stout et al., 2000) or whether CMS procedures could increase apoptosis of BrdU-labeled cells or preexisting neurons in hippocampus during the CMS procedures. Further study will be needed to clarify the resolution of this question.

In addition to glucocorticoid, in vitro studies have demonstrated that incubation with BDNF increases the differentiation of progenitor cells into neurons, but that it does not directly influence the division of progenitor cells (Palmer et al., 1997). In vivo studies suggest that singing behavior upregulates the expression of BDNF in a dose-dependant manner, and that this correlates with the extent of new neuron survival (Li et al., 2000). Moreover, increased apoptosis among hippocampal progenitor cells and excessive neuronal cell death were reported in BDNF knockout mice (Linnarsson et al., 2000), indicating that BDNF is essential for the survival of neurons, specifically of neuronal populations continuously regenerated in the brain. In addition, acute stress was reported to reduce BDNF expression in the hippocampus (Smith et al., 1995). These findings suggest that the downregulation of BDNF in response to stress could reduce the neuron differentiation and survival, but not cell proliferation. In the present study, CMS did not change BDNF mRNA levels in GCL. This finding suggests that CMS is insufficient to reduce BDNF mRNA expression in the GCL and that reduced new-born cell survival occurs in the presence of normal BDNF mRNA expression in the $\mathrm{GCL}$. Although we observed no significant changes in BDNF mRNA levels in CMS-exposed rats, BDNF peptide may have been decreased at normal BDNF mRNA levels. However, similar to the plasma corticosterone levels in response to CMS, we cannot rule out the possibility that BDNF may be decreased during early stage CMS, and that this may play an important role in the reduced survival of new-born cells in the adult rat hippocampus. Further studies will be needed to examine possible changes in BDNF peptide or mRNA levels during the CMS procedures. In addition, this result raises the possibility that other factors may be related to decreased new-born cell survival in rats exposed to CMS. One such candidate is insulin-like growth factor-I (IGF-I). Adult rat hippocampal progenitors incubated with IGF-1 not only proliferated faster, but also promoted neuronal lineage from new-born cells (Aberg et al., 2000). However, it is not known whether stress affects IGF-I levels in the hippocampus. Moreover, in the present study, CMS did not influence the differentiation of BrdU- labeled cells into neurons, raising the possibility that IGF-I levels remained unchanged during the CMS procedures.

Taken together, these results demonstrate that CMS reduces the survival of new-born cells but not of their proliferation, suggesting that repeated mild stress could influence a part of neurogenesis, but not the whole part of neurogenesis. In addition, CMS does not change BDNF mRNA levels in GCL. These results raise the possibility that the survival of new-born cells may be suppressed in the presence of normal BDNF mRNA levels in GCL.

\section{Acknowledgment}

This study was supported by a grant from the Biomedical Brain Research Center (No. 01-PJ8-PG601NE01-0003) and Korea Health 21 R\&D Project (KPGRN-R-04-04) by Ministry of Health and Welfare, Republic of Korea.

\section{References}

Aberg MA, Aberg ND, Hedbacker H, Oscarsson J, Eriksson $P S$. Peripheral infusion of IGF-I selectively induces neurogenesis in the adult rat hippocampus. J Neurosci 2000;20: 2896-903

Armario A, Lopez-Calderon A, Jolin T, Balasch J. Response of anterior pituitary hormones to chronic stress. The specificity of adaptation. Neurosci Biobehav Rev 1986;10:245-50

Bhatnagar S, Meaney MJ. Hypothalamic-pituitary-adrenal function in chronic intermittently cold-stressed neonatally handled and non handled rats. J Neuroendocrinol 1995; 7:97-108

Bremner JD, Narayan M, Anderson ER, Staib LH, Miller HL, Charney DS. Hippocampal volume reduction in major depression. Am J Psychiatry 2000;157:115-8

Cameron HA, Woolley CS, McEwen BS, Gould E. Differentiation of newly born neurons and glia in the dentate gyrus of the adult rat. Neuroscience 1993;56:337-44 
Cameron HA, Gould E. Adult neurogenesis is regulated by adrenal steroids in the dentate gyrus. Neuroscience 1994; 61:203-9

Cole MA, Kalman BA, Pace TW, Topczewski F, Lowrey MJ, Spencer RL. Selective blockade of the mineralocorticoid receptor impairs hypothalamic-pituitary-adrenal axis expression of habituation. J Neuroendocrinol 2000;12:1034-42

Czeh B, Michaelis T, Watanabe T, Frahm J, de Biurrun G, van Kampen M, Bartolomucci A, Fuchs E. Stress-induced changes in cerebral metabolites, hippocampal volume, and cell proliferation are prevented by antidepressant treatment with tianeptine. Proc Natl Acad Sci USA 2001;98:12796-801

De Boer SF, Koopmans SJ, Slangen JL, Van der Gugten J. Plasma catecholamine, corticosterone and glucose responses to repeated stress in rats: effect of interstressor interval length. Physiol Behav 1990;47:1117-24

Di Chiara G, Loddo P, Tanda G. Reciprocal changes in prefrontal and limbic dopamine responsiveness to aversive and rewarding stimuli after chronic mild stress: implications for the psychobiology of depression. Biol Psychiatry 1999;46: 1624-33

Dobrakovova M, Kvetnansky R, Oprsalova Z, Jezova D. Specificity of the effect of repeated handling on sympatheticadrenomedullary and pituitary-adrenocortical activity in rats. Psychoneuroendocrinology 1993;18:163-74

Duman RS, Nakagawa S, Malberg J. Regulation of adult neurogenesis by antidepressant treatment. Neuropsychopharmacology 2001;25:836-44

Gould E, McEwen BS, Tanapat P, Galea LA, Fuchs E. Neurogenesis in the dentate gyrus of the adult tree shrew is regulated by psychosocial stress and NMDA receptor activation. J Neurosci 1997;17:2492-8

Gould E, Beylin A, Tanapat P, Reeves A, Shors TJ. Learning enhances adult neurogenesis in the hippocampal formation. Nat Neurosci 1999;2:260-5

Gould E, Gross CG. Neurogenesis in adult mammals: some progress and problems. J Neurosci 2002;22:619-23

Hastings NB, Gould E. Rapid extension of axons into the CA3 region by adult-generated granule cells. J Comp Neurol 1999;413:146-54

Hauger RL, Lorang M, Irwin M, Aguilera G. CRF receptor regulation and sensitization of $A C T H$ responses to acute ether stress during chronic intermittent immobilization stress. Brain Res 1990;532:34-40

Kempermann G, Kuhn HG, Gage FH. More hippocampal neurons in adult mice living in an enriched environment. Nature 1997;386:493-5

Kim BJ, Kim SS, Kim YI, Paek SH, Lee YD, Suh-Kim H. Forskolin promotes astroglial differentiation of human central neurocytoma cells. Exp Mol Med 2004;36:52-6

Kim SJ, Lee KJ, Shin YC, Choi SH, Do EJ, Kim SD, Chun $B G$, Lee MS, Shin KH. Stress-induced decrease of granule cell proliferation in adult rat hippocampus: assessment of granule cell proliferation using high doses of bromodeoxyuridine before and after restraint stress. Mol Cells 2005; 19:74-80
Lee EJ, Lee HG, Park SH, Choi EY, Park SH. CD99 type II is a determining factor for the differentiation of primitive neuroectodermal cells. Exp Mol Med 2003;35:438-47

Li XC, Jarvis ED, Alvarez-Borda B, Lim DA, Nottebohm F. A relationship between behavior, neurotrophin expression, and new neuron survival. Proc Natl Acad Sci USA 2000; $97: 8584-9$

Li YF, Zhang YZ, Liu YQ, Wang HL, Yuan L, Luo ZP. Moclobemide up-regulates proliferation of hippocampal progenitor cells in chronically stressed mice. Acta Pharmacol Sin 2004;25:1408-12

Linnarsson $S$, Willson CA, Ernfors P. Cell death in regenerating populations of neurons in BDNF mutant mice. Brain Res Mol Brain Res 2000;75:61-9

Malberg JE, Eisch AJ, Nestler EJ, Duman RS. Chronic antidepressant treatment increases neurogenesis in adult rat hippocampus. J Neurosci 2000;20:9104-10

Moreau JL, Bos M, Jenck F, Martin JR, Mortas P, Wichmann J. 5HT2C receptor agonists exhibit antidepressant-like properties in the anhedonia model of depression in rats. Eur Neuropsychopharmacol 1996;6:169-75

Nowakowski RS, Lewin SB, Miller MW. Bromodeoxyuridine immunohistochemical determination of the lengths of the cell cycle and the DNA-synthetic phase for an anatomically defined population. J Neurocytol 1989;18:311-8

Palmer TD, Takahashi J, Gage FH. The adult rat hippocampus contains primordial neural stem cells. Mol Cell Neurosci 1997;8:389-04

Paxinos G, Watson C. The Rat Brain in Stereotaxic Coordinates. 3rd Ed, 1997, Academic Press, Inc., San Diego

Reagan LP, McEwen BS. Controversies surrounding glucocorticoid-mediated cell death in the hippocampus. J Chem Neuroanat 1997;13:149-67

Sapolsky RM. Stress, glucocorticoids, and damage to the nervous system: the current state of confusion. Stress 1996;1:1-9

Smith MA, Makino S, Kvetnansky R, Post RM. Stress and glucocorticoids affect the expression of brain-derived neurotrophic factor and neurotrophin-3 mRNAs in the hippocampus. J Neurosci 1995;15:1768-77

Stout SC, Mortas P, Owens MJ, Nemeroff CB, Moreau J. Increased corticotropin-releasing factor concentrations in the bed nucleus of the stria terminalis of anhedonic rats. Eur J Pharmacol 2000;401:39-46

Tanapat P, Galea LA, Gould E. Stress inhibits the proliferation of granule cell precursors in the developing dentate gyrus. Int J Dev Neurosci 1998;16:235-9

Tanapat P, Hastings NB, Reeves AJ, Gould E. Estrogen stimulates a transient increase in the number of new neurons in the dentate gyrus of the adult female rat. J Neurosci 1999;19:5792-801

Tanapat P, Hastings NB, Rydel TA, Galea LA, Gould E. Exposure to fox odor inhibits cell proliferation in the hippocampus of adult rats via an adrenal hormone-dependent mechanism. J Comp Neurol 2001;437:496-504 
Vicario-Abejon C, Johe KK, Hazel TG, Collazo D, McKay $\mathrm{RD}$. Functions of basic fibroblast growth factor and neurotrophins in the differentiation of hippocampal neurons. Neuron 1995;15:105-14
Zigova T, Pencea V, Wiegand SJ, Luskin MB. Intraventricular administration of BDNF increases the number of newly generated neurons in the adult olfactory bulb. Mol Cell Neurosci 1998;11:234-45 